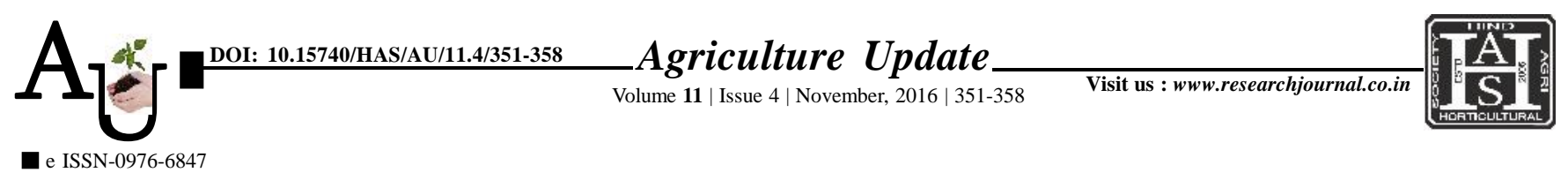

\title{
Research article: An analysis of the marketing effectiveness of the farmers
}

\section{SUSHIL KUMAR, RASHMI SINGH AND VIKRAM YOGI}

Article Chronicle : Received :

27.07.2016;

Revised :

16.09.2016;

Accepted :

02.10 .2016

KEY Words :

Marketing

effectiveness,

Price spread,

Marketing margin

Author for correspondence :

\section{SUSHIL KUMAR}

Division of Agricultural

Extension, Indian

Agricultural Research

Institute, NEW DELHI,

INDIA

Email: sushilnb29@

gmail.com

See end of the article for

authors' affiliations
SUMMARY : This research was aimed at assessing the effectiveness of marketing services. The study was conducted in Faridabad from Haryana, Hapur from Uttar Pradesh and North-West Delhi from Delhi selected purposively to explore the marketing extension system as they adequately represent the periurban agriculture. 90 farmers, 30 rice, wheat and tomato grower farmers from each district were selected to constitute the total sample size. Interview schedule were used in eliciting information from the farmers. Effectiveness were analysed using indicators specifically marketable surplus, producer share in consumer prices, middlemen share in consumer prices, marketing cost, marketing margin, price spread and marketing efficiency using Shepherd's equation. The study found that marketing cost is high when more intermediaries are involved in marketing of produce. Producer's share in consumer's price is high when produce is directly sold to consumer by producer. Marketing efficiency of cereals is high than vegetable crop because of heavy transport and post harvest losses occur in vegetables.

How to cite this article : Kumar, Sushil, Singh, Rashmi and Yogi, Vikram (2016). An analysis of the marketing effectiveness of the farmers. Agric. Update, 11(4): 351-358; DOI : 10.15740/HAS/AU/11.4/351-358. 